\title{
PSYCHOLOGICAL STRESS AND BREAST CANCER INCIDENCE: A SYSTEMATIC REVIEW
}

\author{
VALENTINA-FINETA CHIRIAC ${ }^{1}$, ADRIANA BABAN ${ }^{2}$, \\ DAN L. DUMITRASCU ${ }^{1}$
}

\author{
${ }^{1}$ Iuliu Hatieganu University of Medicine and Pharmacy Cluj-Napoca, Romania \\ ${ }^{2}$ Department of Psychology, Babes Bolyai University Cluj-Napoca, Romania
}

\begin{abstract}
Objective. Breast cancer is the world's leading cause of cancer mortality in women. Stress is an imminent risk factor with a documented negative impact on neuroendocrine and immune system. Numerous epidemiological studies have investigated the link between stress and cancer, reporting contradictory results from no association to a close causal link. The impact of the topic and the lack of conclusion compelled this systematic review.

Methods. A systematic review was carried out, including all literature studies from 1966 to 2016, investigating the relationship between stress and the occurrence of breast cancer. Of the 1813 articles identified in the PubMed/Medline database, 52 were eligible and included in the analysis.

Results. A number of 17 retrospective, 20 limited prospective and 15 prospective studies were analyzed. The number of patients exceeded 29,000, for a total number of more than 700.000 women recruited from hospital, screening cohorts or population registers. We identified 26 positive articles linking personal traits, stressful events and breast cancer, 18 negative articles that did not confirm their hypothesis and 8 articles that could not be classified. Facing heterogeneity, all possible misguiding factors such as: study design, information gathering, stress type, moment of exposure, individual susceptibility and personality, were discussed independently.

Conclusions. Qualitative analysis of articles has revealed a possible association between stress and cancer, especially regarding stressful life events. In the absence of a meta-analysis and taking into account the methodological heterogeneity of the studies, the results are difficult to interpret and the role of chance is difficult to exclude.
\end{abstract}

Keywords: breast cancer, incidence, life events, stress

\section{Background and aims}

Breast cancer represents the leading cause of death by cancer in women [1]. Only around $50 \%$ of mammary carcinoma can be attributed to a physiological, behavioral or genetic risk factor [2]. Additionally, new risk factors have been studied, including psychological stress, smoking and nutrition: their management and exclusion may offer great benefit.

Mind-body symbiosis has its roots in antique Greece through the writings of Hippocrates and Galen who

Manuscript received: 25.09.2017

Accepted: 27.10.2017

Address for correspondence: ddumitrascu@umfcluj.ro observed an increase in breast cancer incidence among the melancholic compared with the sanguine women. The connection between "psyche" and cancer remains mostly anecdotal till the end of 19th century, when Dr. Snow [3] reported in his paper that 156 out of 200 women with breast cancer had suffered a traumatic life event, usually the loss of a dear person.

The knowledge accumulated in the 20th century regarding stress and its mechanism of action combined with the enthusiasm regarding the impact of stress hormones in cancer development has led to numerous research studies. Strong, but empirical hypotheses sustaining stress cancerogenesis have appeared. However, 
results from epidemiologic studies have been conflicting and ranged from no association between stress and breast cancer, with an $\mathrm{OR}=0.95$ [4] up to a close link between the two with $\mathrm{OR}=11.6$ [5]. Moreover, the meta-analyses [6-12] completed over the years have resulted in the same inconstancy and failed to provide a creditable conclusion.

The main objective of the present systematic review is to examine the relationship between psychological stress and the risk of breast cancer. The question we want to answer is: Are women exposed to stress more prone to develop breast cancer than women who are non-exposed?

\section{Methods}

A search was conducted on the PubMed database, using various combinations of the following keywords: "stress", "psychological stress", "life events" and "breast or mammary cancer, carcinoma or neoplasm". Search interval had no temporal limits. All published articles identified, with no time limit, were then screened based on title and abstract. The potential eligible studies were then obtained in full-text and verified in order to meet the inclusion and exclusion criteria. The reference list of these articles was also consulted in order to identify studies that were not initially found or had been omitted. In order to evaluate the methodological quality of the studies, each article was subjected to the Downs and Black control list [13].

The inclusion and exclusion criteria are listed below:

Inclusion criteria: 1. Case-control, cohort or randomized studies 2. Studies conducted on women older than 18 years, diagnosed with primary breast cancer 3 . Prospective studies with a minimum 5 years follow-up 4 . Studies that included a quantitative or semi-quantitative method of stress measurement 5. Studies written in English, Romanian or French.

Exclusion criteria: 1. Studies that analyzed stress caused by lifestyle, work environment or posttraumatic stress disorder. 2. Studies that analyzed stress in women with a medical psychiatric history. 3. Studies that implied the role of stress in the recurrence or in the prognosis of breast cancer. 4. Studies that involved treatment as a stress factor. 5. Studies that included the use of non-conventional therapy (massage, reflexology, acupuncture, mindfulness) for stress reduction. 6. Reviews, meta-analysis and editorials.

\section{Results}

Using the search strategy described above, from 1966 to March 2016, a number of 1813 articles were screened with a total of 52 articles selected for the final analysis (Figure 1). The articles were case-control or cohort studies, having level II or III of evidence [14]. All studies received a satisfactory DB evaluation, were considered qualitative and were included. Selected articles were reviewed and the main data were summarized. For each article included in the present study, the year of publication, type of study, number of patients/controls, the type of stress and the time period evaluated, as well as the main results were extracted (Table I-III).
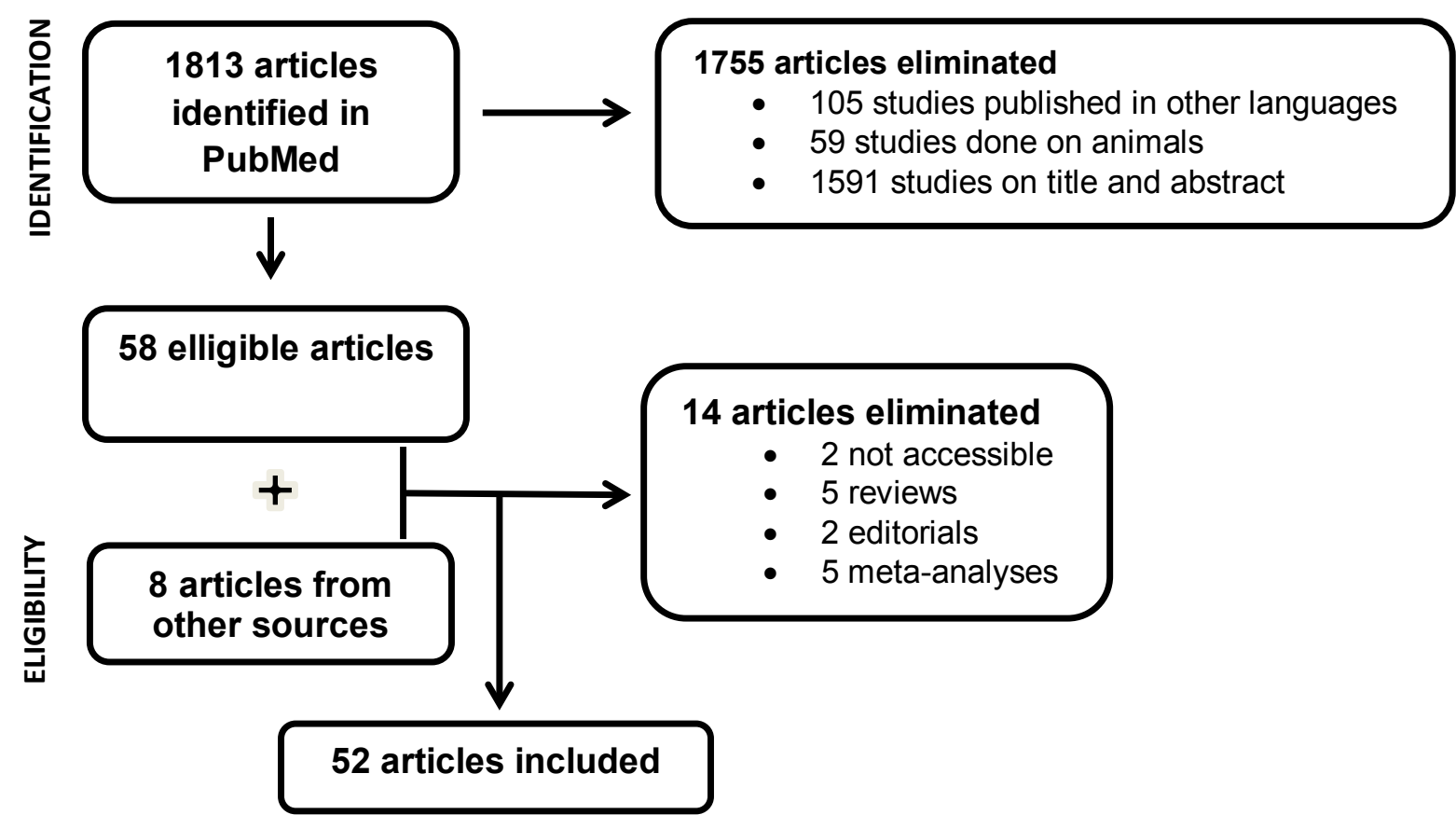

Figure 1. Diagram of article selection. 
Table I. Summary of retrospective studies.

\begin{tabular}{|c|c|c|c|c|c|c|}
\hline $\begin{array}{l}\text { Name of first } \\
\text { author and year of } \\
\text { publication }\end{array}$ & Study design & $\begin{array}{l}\text { Number of cases/ } \\
\text { control1/ } \\
\text { control2 }\end{array}$ & 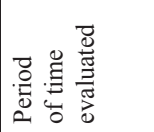 & $\begin{array}{l}\text { Type of stress/ role of } \\
\text { personality }\end{array}$ & $\begin{array}{l}\text { Results } \\
\text { (Personality traits of patients) }\end{array}$ & $\begin{array}{l}\text { Downs } \\
\text { Black } \\
\text { Score } \\
\text { (DB) }\end{array}$ \\
\hline $\begin{array}{l}\text { Snell [25] } \\
1971\end{array}$ & Case-control & $352 / 670$ & 5 years & Life events & $\begin{array}{l}\text { No differences between groups in } \\
\text { separations, divorces, family illness or a } \\
\text { range of other life events. }\end{array}$ & 9 \\
\hline $\begin{array}{l}\text { Jansen }[20] \\
1984\end{array}$ & Case-control & $69 / 71 / 82$ & $?$ & Personality & $\begin{array}{l}\text { Timid, non-assertive, non-competitive, } \\
\text { calm, less aggressive, easy-going, and } \\
\text { keeping anger inside }\end{array}$ & 14 \\
\hline $\begin{array}{l}\text { Watson [21] } \\
1984\end{array}$ & Case-control & $30 / 27$ & $?$ & Personality & $\begin{array}{l}\text { Tendency to control anger, repressive } \\
\text { coping style, less curious, no difference in } \\
\text { trait anxiety and anger }\end{array}$ & 13 \\
\hline $\begin{array}{l}\text { Priestman }[22] \\
1985\end{array}$ & Case-control & $\begin{array}{l}100 / \\
100 / 100\end{array}$ & 3 years & Life events & $\begin{array}{l}\text { No difference between cases and controls } \\
\text { in life events; Controls reported more life } \\
\text { events than other two groups. }\end{array}$ & 12 \\
\hline $\begin{array}{l}\text { Bremond [23] } \\
1986\end{array}$ & Case-control & $50 / 105$ & 5 years & Life events & $\begin{array}{l}\text { More negative events in the case } \\
\text { group. Tendency to suppress feelings, } \\
\text { commitment to social norms, }\end{array}$ & 12 \\
\hline $\begin{array}{l}\text { Ewertz [26] } \\
1986\end{array}$ & Case-control & $\begin{array}{l}1782 / \\
1738\end{array}$ & $3-15$ years & $\begin{array}{l}\text { Divorce and husband } \\
\text { death }\end{array}$ & $\begin{array}{l}\mathrm{RR}=0.9(0.7-1.2) \text { divorce } \\
\mathrm{RR}=0.8(0.7-1.0) \text { husband death }\end{array}$ & 13 \\
\hline $\begin{array}{l}\text { Scherg [31] } \\
1988\end{array}$ & Case-control & $508 / 1563$ & $>10$ years & Life events & $\begin{array}{l}\mathrm{OR}=1.10 \text { father's death early in life } \\
\mathrm{OR}=1.71 \text { mother's death early in life } \\
\mathrm{OR}=1.45 \text { divorce or husband's death }\end{array}$ & 13 \\
\hline $\begin{array}{l}\text { Forsen [24] } \\
1991\end{array}$ & Case-control & $87 / 87$ & 6 years & Life events & $\begin{array}{l}\mathrm{RR}=5.02(1.72-14.7) \text { important emotional } \\
\text { loses }\end{array}$ & 13 \\
\hline $\begin{array}{l}\text { Roberts [4] } \\
1996\end{array}$ & Case-control & $258 / 614$ & 5 years & Life events & $\mathrm{OR}=0.9(0.78-1.05)$ stressful life events & 15 \\
\hline $\begin{array}{l}\text { Ginsberg [19] } \\
1996\end{array}$ & Case-control & $99 / 99$ & $2 \& 10$ years & Life events & $\begin{array}{l}\mathrm{RR}=2.24(0.92-5.44) \\
\text { distress score }>210 \text { than those with }<70 \\
\text { at } 10 \text { years } \\
4.67(1.33-16.41) \\
\text { change score }>210 \text {, than those with }<70 \text { at } \\
10 \text { years }\end{array}$ & 15 \\
\hline $\begin{array}{l}\text { Kruk [27] } \\
2004\end{array}$ & Case-control & $257 / 565$ & $>5$ years & Life events & $\mathrm{OR}=3.70(2.61-5.26)$ major life events & 15 \\
\hline $\begin{array}{l}\text { Peled [28] } \\
2008\end{array}$ & Case-control & $255 / 367$ & Any period & Life events & $\begin{array}{l}\mathrm{OR}=1.62(1.09-2.40) \text { more than one } \\
\text { stressful event }\end{array}$ & 14 \\
\hline $\begin{array}{l}\text { Keinan }[32] \\
2009\end{array}$ & Cohort & $\begin{array}{l}11822 / \\
315544\end{array}$ & $\sim 44$ years & Holocaust & $\begin{array}{l}\mathrm{RR}=2.44(1.46-4.06) \text { for the youngest } \\
\text { birth cohort }\end{array}$ & 14 \\
\hline $\begin{array}{l}\text { Tas [29] } \\
2012\end{array}$ & Case-control & $276 / 492$ & 1year & Life events & $\begin{array}{l}\text { Stressful events of patient vs control } \\
(41.9 \% \text { vs. } 31.7 \%, \mathrm{P}=0.04)\end{array}$ & 13 \\
\hline $\begin{array}{l}\text { Kruk }[30] \\
2012\end{array}$ & Case-control & $858 / 1085$ & $>5$ years & Life events & $\begin{array}{l}\mathrm{OR}=3.95(2.39-6.55) \text { severe personal } \\
\text { ilness } \\
\mathrm{OR}=3.74(1.99-7.03) \text { legal problems } \\
\mathrm{OR}=3.14(2.18-4.54) \text { death of a close } \\
\text { friend/relative }\end{array}$ & 15 \\
\hline $\begin{array}{l}\text { Toleutay [17] } \\
2013\end{array}$ & Case-control & $114 / 196$ & $?$ & $\begin{array}{l}\text { Chronic and familial } \\
\text { stress }\end{array}$ & $\begin{array}{l}\mathrm{OR}=3.61(1.75-7.45) \text { chronic stress } \\
\mathrm{OR}=4.86(2.59-9.12) \text { stress in the family }\end{array}$ & 14 \\
\hline $\begin{array}{l}\text { Wang [16] } \\
2013\end{array}$ & Case-control & $157 / 314$ & 1 month & Stress in general & $\begin{array}{l}\mathrm{OR}=1.65(1.10-2.47) \text { high perceived } \\
\text { stress }\end{array}$ & 15 \\
\hline
\end{tabular}


Table II. Summary of limited-prospective studies .

\begin{tabular}{|c|c|c|c|c|c|}
\hline $\begin{array}{l}\text { Name of first author } \\
\text { and year of publication }\end{array}$ & $\begin{array}{l}\text { Number of cases/ } \\
\text { control1/ control } 2\end{array}$ & 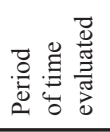 & $\begin{array}{l}\text { Type of stress/ Role } \\
\text { of personality }\end{array}$ & Results & $\begin{array}{l}\text { DB } \\
\text { Score }\end{array}$ \\
\hline $\begin{array}{l}\text { Schonfield* }[46] \\
1975\end{array}$ & $27 / 85$ & 3 years & Life events & Controls reported more events, no differences regarding deaths & 13 \\
\hline $\begin{array}{l}\text { Greer* }[42] \\
1975\end{array}$ & $69 / 91$ & 5 years & $\begin{array}{l}\text { Personality and } \\
\text { Life events }\end{array}$ & $\begin{array}{l}\text { No differences in type or amount of stress. } \\
\text { Abnormal release of emotions: suppression of anger. }\end{array}$ & 14 \\
\hline $\begin{array}{l}\text { Morris* [43] } \\
1981\end{array}$ & $17 / 33$ & ? years & $\begin{array}{l}\text { Personality and } \\
\text { Life events }\end{array}$ & $\begin{array}{l}\text { Patients experience less frequently: anger, losing control in anger, } \\
\text { neuroticism }\end{array}$ & 14 \\
\hline $\begin{array}{l}\text { Scherg*[47] } \\
1981\end{array}$ & $\begin{array}{l}100 / \\
100 / 69\end{array}$ & 3 years & Life events & $\begin{array}{l}\text { Cases report more deaths of close relative than controls ( } 46 \% \mathrm{v} \text {. } \\
31 \%) \text {. }\end{array}$ & 13 \\
\hline $\begin{array}{l}\text { Wirsching* }[50] \\
1985\end{array}$ & $18 / 38$ & $?$ & Personality & $\begin{array}{l}\text { Patients are inaccessible, altruistic, suppressing feelings, } \\
\text { rationalizing, harmonizing, optimistic }\end{array}$ & 13 \\
\hline $\begin{array}{l}\text { Cheang* [34) } \\
1985\end{array}$ & $46 / 75 / 42$ & 2 years & Life events & $\begin{array}{l}\text { Cases had higher life events scores than controls; Cases report more } \\
\text { illness events than controls }(78 \% \text { v. } 50 \%) \text {. }\end{array}$ & 13 \\
\hline $\begin{array}{l}\text { Scherg* [48] } \\
1987\end{array}$ & $75 / 75$ & $\begin{array}{l}\text { Any } \\
\text { period }\end{array}$ & Personality & $\begin{array}{l}\text { Patients show less anxiety, less pattern A, more social desirability, } \\
\text { more war experiences }\end{array}$ & 12 \\
\hline $\begin{array}{l}\text { Grassi* [41] } \\
1988\end{array}$ & $41 / 35$ & $?$ & Personality & $\begin{array}{l}\text { Patients present less state hostility and irritability. More emotional } \\
\text { suppression. }\end{array}$ & 12 \\
\hline $\begin{array}{l}\text { Todarello* }[49] \\
1989\end{array}$ & $13 / 187$ & $?$ & Alexithymia & Patients have more alexithymic traits & 13 \\
\hline $\begin{array}{l}\text { Cooper* [35] } \\
1989\end{array}$ & $\begin{array}{l}171 / 1265 \\
727\end{array}$ & 2 years & Life events & $\begin{array}{l}\text { Husband's or close friend's death are related with the occurrence } \\
\text { and severity of disease }\end{array}$ & 13 \\
\hline $\begin{array}{l}\text { Edwards* [37] } \\
1990\end{array}$ & $\begin{array}{l}79 / 505 / \\
397\end{array}$ & 2 years & Life events & No difference on life event scales, coping, Type A or social support & 14 \\
\hline $\begin{array}{l}\text { Anagnostopoulos* [33] } \\
1993\end{array}$ & $\begin{array}{l}180 / 156 / \\
112\end{array}$ & $?$ & Alexithymia & No differences & 15 \\
\hline $\begin{array}{l}\text { Cooper* [36] } \\
1993\end{array}$ & $171 / 1265 / 727$ & 2 years & Life events & Loss-related events are associated with increased risk of cancer & 13 \\
\hline $\begin{array}{l}\text { Geyer* [40] } \\
1993\end{array}$ & $33 / 59$ & 8 years & Life events & $\begin{array}{l}\text { Cases report more severe 'contextual threats' }(48 \%) \text { than controls } \\
(10 \%) \text { and more severe loss events }(45 \% \text { v. } 12 \%) \text { than controls. }\end{array}$ & 13 \\
\hline $\begin{array}{l}\text { Fox* [39] } \\
1994\end{array}$ & $\begin{array}{l}20 / 488 / \\
266\end{array}$ & 2 years & $\begin{array}{l}\text { Life events and } \\
\text { loneliness }\end{array}$ & $\begin{array}{l}\text { Patients have more often experienced the death of a spouse or close } \\
\text { family member }\end{array}$ & 15 \\
\hline $\begin{array}{l}\text { Chen* [5] } \\
1995\end{array}$ & $41 / 78 / 50$ & 5 years & Life events & $\begin{array}{l}\mathrm{OR}=7.08(2.31-21.65) \text { great thread } \\
\mathrm{OR}=11.64(3-10 \text { to } 43-66) \text { severe thread }\end{array}$ & 15 \\
\hline $\begin{array}{l}\text { Protheroe* }[45] \\
1999\end{array}$ & $\begin{array}{l}106 / \\
226\end{array}$ & 5 years & Life events & $\begin{array}{l}\mathrm{OR}=0.91(0.47-1.81) \text { more than } 1 \text { severe life event } \\
\mathrm{OR}=0.86(0.41-1.81) \text { life difficulties }\end{array}$ & 14 \\
\hline $\begin{array}{l}\text { Price* [18] } \\
2001\end{array}$ & $\begin{array}{l}239 / \\
275\end{array}$ & 2 years & Life events & $\begin{array}{l}\text { OR=9.39 (1.90-46.42) highly threatening stress without emotional } \\
\text { social support }\end{array}$ & 15 \\
\hline $\begin{array}{l}\text { Ollonen* }[44] \\
2005\end{array}$ & $34 / 28 / 53$ & 10 years & Life events & $\begin{array}{l}\text { Association found for very severe and severe losses }(P=0.02) \text { and } \\
\text { greater number of moderate or severe losses }(P=0.0009)\end{array}$ & 14 \\
\hline $\begin{array}{l}\text { Eskelinen* [38] } \\
2010\end{array}$ & $34 / 28 / 53$ & 10 years & $\begin{array}{l}\text { Difficult childhood } \\
\text { and adolescence }\end{array}$ & $\begin{array}{l}\text { Association found for deficit in childhood }(\mathrm{P}<0.05) \text { or severe } \\
\text { deficit in childhood }(\mathrm{P}=0.02)\end{array}$ & 14 \\
\hline
\end{tabular}

* case-control 
Table III. Summary of prospective studies.

\begin{tabular}{|c|c|c|c|c|c|c|}
\hline $\begin{array}{l}\text { Name of first author } \\
\text { and year of publication }\end{array}$ & Design & $\begin{array}{l}\text { Number cases/ } \\
\text { controls- cohort }\end{array}$ & 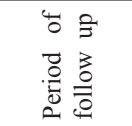 & $\begin{array}{l}\text { Type of } \\
\text { stress/ role of } \\
\text { personality }\end{array}$ & Results & $\begin{array}{l}\text { DB } \\
\text { Score }\end{array}$ \\
\hline Hagnell [15] 1966 & Case-control & $\begin{array}{l}9 / \\
2550\end{array}$ & 10 years & Personality & $\begin{array}{l}\text { No associations between cancer risk and validity, } \\
\text { solidity, and capacity; }\end{array}$ & 9 \\
\hline Reynolds [55] 1990 & Cohort & $\begin{array}{l}71 / \\
6848\end{array}$ & 17 years & Social support & $\begin{array}{l}\text { Association between social isolation and breast } \\
\text { cancer }\end{array}$ & 14 \\
\hline Scherg [54] 1993 & Case-control & $\begin{array}{l}48 / \\
2874\end{array}$ & 11 years & Personality & $\begin{array}{l}\text { No association with: personality factors and } \\
\text { background factors. Association with: health-related } \\
\text { problems }\end{array}$ & 13 \\
\hline Kvikstad [52] 1994 & Case-control & $\begin{array}{l}4491 / \\
44910\end{array}$ & $?$ & $\begin{array}{l}\text { Divorce and } \\
\text { husband's death }\end{array}$ & $\begin{array}{l}\mathrm{OR}=0.83(0.75-0.92) \text { divorce } \\
\mathrm{OR}=1.13(0.94-1.36) \text { husband's death }\end{array}$ & 14 \\
\hline Bleiker [53] 1996 & Case-control & $\begin{array}{l}131 / \\
9705\end{array}$ & 5 years & Personality & $\begin{array}{l}\text { Weak association between: anti-emotionality and } \\
\text { breast cancer incidence. }\end{array}$ & 15 \\
\hline Johansen [57] 1997 & Cohort & $\begin{array}{l}198 / \\
5716\end{array}$ & $1-50$ years & $\begin{array}{l}\text { Cancer and } \\
\text { child's death }\end{array}$ & $\begin{array}{l}\text { No relation between cancer in child and cancer in } \\
\text { parent }\end{array}$ & 16 \\
\hline Jacobs [56] 2000 & Cohort & $\begin{array}{l}39 / \\
1213\end{array}$ & $>20$ years & $\begin{array}{l}\text { Parent's death } \\
\text { and other events }\end{array}$ & $\begin{array}{l}\mathrm{OR}=2.56(1.59-4.35) \\
\text { mother's death in childhood }\end{array}$ & 18 \\
\hline Helgesson [59] 2003 & Cohort & $\begin{array}{l}49 / \\
1462\end{array}$ & 24 years & Life events & $\mathrm{RR}=2.1(1.2-3.7)$ stress & 18 \\
\hline Lillberg [58] 2003 & Cohort & $\begin{array}{l}180 / \\
10808\end{array}$ & 14 years & Life events & $\begin{array}{l}\mathrm{HR}=2.26(1.25-4.07) \text { divorce } \\
\mathrm{HR}=2.00(1.03-3.88) \text { husband's death } \\
\mathrm{HR}=1.36(1.00-1.86) \text { close relative or friend's death }\end{array}$ & 18 \\
\hline Kroenke [61] 2004 & Cohort & $\begin{array}{l}1700 / \\
69886\end{array}$ & 8 years & Nursing & $\mathrm{RR}=1.19(0.87-1.62)>15$ hours of nursing $/$ week & 16 \\
\hline Lambe [51] 2004 & Case-control & $617 / 141798$ & 34 years & Child's death & $\begin{array}{l}\mathrm{OR}=2.65(1.06-6.60) \text { loss of a child between the } \\
\text { ages of } 1 \text { and } 4 \text { for uniparous }\end{array}$ & 15 \\
\hline Nielsen [62] 2005 & Cohort & $\begin{array}{l}251 / \\
6689\end{array}$ & $\begin{array}{l}16-18 \\
\text { years }\end{array}$ & Daily stress & $\mathrm{HR}=0.60(0.37-0.97)$ high stress & 18 \\
\hline Surtees [63] 2009 & Cohort & $\begin{array}{l}313 / \\
11467\end{array}$ & 9 years & Life events & $\begin{array}{l}\mathrm{HR}=1.02(0.91-1.16) \text { difficulties in childhood } \\
\mathrm{HR}=0.99(0.89-1.11) \text { life events }\end{array}$ & 16 \\
\hline Metcalfe [60] 2007 & Cohort & $\begin{array}{l}62 / \\
991\end{array}$ & 30 years & Daily stress & $\begin{array}{l}\mathrm{HR}=2.16(1.00-4.71) \text { moderate stress } \\
\mathrm{HR}=1.92(0.81-4.55) \text { high stress }\end{array}$ & 18 \\
\hline Michael [64] 2009 & Cohort & $\begin{array}{l}2481 / \\
84334\end{array}$ & 8 years & Life events & $\mathrm{HR}=1.12(1.0-1.25)$ one life event & 18 \\
\hline
\end{tabular}

The 52 studies were spread over a period of 47 years, the oldest dating back to 1966 [15] and the newest being published in 2013 [16,17]. With some exceptions $[16,18,19]$ most studies came from European countries or from the USA. All articles were published in English.

We divided the studies based on design, identifying 16 retrospective case-control studies [4,16,17,19-31], 1 retrospective cohort study [32], 20 limited-prospective studies [5,18,33-50], 5 prospective case-control studies [15,51-54] and 10 prospective cohort studies [55-64]. There were two cases of 2 studies that analyzed the same population $[35,36,38,44]$, but because they measured different variables and had different results, were considered as individual studies. The total number of breast cancer cases analyzed was 29,057 for a total participation of almost 700,000 women.

Regarding participant selection, cases were selected either from the hospital for 9 studies [16,20-25,29,31] or from the general population for 22 studies $[4,15,17,19,26$ -
28,30,32,51,52,54-64]. Patients were also selected from a cohort of women with suspicious lesion in 18 studies $(5,33-$ $46,48-50$ ) or from a screening cohort for 3 studies [18,47,53]. For the case-control studies the control group was selected from the hospital $[16,20,21,23,25,27-31,54]$ or from the general population $[4,15,17,19,22,24,26,52,53,32,55-54]$.

In the case of limited prospective studies, 10 were conducted on women that were scheduled for biopsy of a suspicious breast lesion [5,18,34,40-43,45,46,50], 3 on women that were waiting for a prophylactic or symptomdirected mammography $[37,39,49]$ and 5 on women that were having a routine check-up with or without symptoms $[33,35,36,38,44]$.

As an investigation method, 42 of 52 researchers used questionnaires accompanied or not by a medical consultation, 5 used exclusively the interview $[15,25,42,50,56]$, and 5 retrieved information from population-based registries $[26,32,51,52,57]$. The scales utilized for results quantification varied from study to 
study, no comparison being able to be made.

More than two-thirds of the articles analyzed stress produced by important life events, such as: the death of a husband, child, parent or close friend, divorce, financial problems, personal or familial medical problems and living in a political or cultural difficult period or region. Only two studies investigated daily stress $[60,62]$ and 10 studies were based on highlighting the link between personality traits, the way of coping with stress and breast cancer $[15,20,21,33,41,48-50,53,54]$.

In the retrospective studies participants were asked to remember stress exposure between 1 month [16] and any previous period [28]. The limited prospective studies had a minimum of two years between the stress exposure and diagnosis, whereas prospective studies had a minimum 5 years follow up. The longest periods analyzed were in the registries based studies, going up to 50 years [57].

We identified 26 positive articles that reported a link between stress and breast cancer, and 18 articles defined as negative that did not validate their hypothesis. The positive ones were 11 retrospective $[16,17,19,23,24,27$ 32], 10 prospective limited [5,18,34-36,38-40,44,48] and 5 prospective $[55,56,58-60]$. The negative were 4 retrospective $[4,22,25,26], 6$ prospective limited $[37,42,43,45,46,47]$ and 8 prospective $[51,52,54,57,61-64]$.

\section{Discussion}

A number of 52 studies that analyzed the connection between stress and the risk of breast cancer development were identified. Of these, 26 validated their primary idea, concluding that a relation does exist between stress and cancer, whereas 18 did not sustain this hypothesis with sufficient data. The remaining 8 studies were focused on personality traits, and we considered it erroneous to appoint them as positive, even if there were differences between patients and controls personality. Regarding numerical power, the positive studies included more than 15,500 patients, with only around 13,000 patients in the negative group.

The information gathered tends to tip the balance toward an affirmative answer to our initial question. Yes, the women exposed to stress are at a higher risk of developing breast cancer than the non-exposed. This statement must be interpreted cautiously. In the absence of a meta-analysis, there are several elements that can induce judgment errors.

If the role of psychosocial factors is modest or even non-existent, does the inconsistency lie in the research methods? All the possible misguiding factors must be taken into consideration. These are discussed separately below.

\section{a. The Study design}

The study design is well acknowledged to influence results. This is shown even in this particular area of research by the meta-analysis of Duijits [7] who reports differences in the calculated risk between retrospective and prospective studies. Retrospective studies have many drawbacks, the most important being the recall error. The validity of results is mostly dependent on subject memory, which can sometimes be misleading. Even so, there are studies showing that the severity of the event is proportional with reporting reliability, because a major incident brings a deep remembrance [65]. Limited prospective studies obtain information just before a biopsy and the results can be biased by the reaction to the suspected diagnosis, usually overestimating the importance of an event. Real prospective studies are considered the most objective, but because of the long time required with an imminent loss of participants, some types of personality may be selected.

In our review we had only 15 prospective trials, and most of them were negative. Only $19 \%$ of positive studies were prospective, whereas, almost half of the negative ones had a prospective design.

\section{b. Information gathering}

Another major issue is represented by the large variety of methods used for obtaining information as well as by the method of data quantification which limits the objective comparison and interpretation of results. The questionnaires were extremely heterogeneous, with only a few validated forms used: Life events inventory [19,58], The Holmes-Rahe Social Readjustment Rating Scale $[4,24,27,35,46]$ and the Brown-Harris Life Events and Difficulties Schedule $(5,18,40,45)$. Questions with a Yes/ No answer [23] as well as open answer questions [27] were present. For example [4] in one of the studies the great availability rate was considered to be due to the short and easy questionnaire: the abbreviated Life event inventory. Even if validated as a standardized tool [66] it represents a simplistic method to detect a relation between cancer and stress leaving results open to criticism. Moreover, gathering information over the phone seems unprofessional with a great probability of superficiality and biases. On the other hand, the interview, being open to much more subjectivity, is also far from the ideal way of collecting data.

Some studies $[4,58]$ have used only the life events number, on the principle of more events $=$ more stress, while others have included weighting scales for intensity measurement $[19,46]$. As an example, Protheroe [45] divided women into four groups using only one variable (1, 2- minor stress, 3, 4- major stress), while Ginsberg [19] used the Tennant/Andrews system. Similarly, other studies divided the researched group into five $[5,38,44]$ or six [62] clusters based on stress level.

\section{c. Stress type}

Analyzing the same type of stress has led to opposed results. As an example: child death as a major stress has not influenced the risk of breast cancer in mothers, in Johansen's study [57], whereas the team conducted by Lambe [51] reported an increase of risk, valid just for the uniparous women whose child was 1 and 4 years at the time of death.

Other life events, like death of husband or divorce, 
were the most frequently studied with a trend towards validating a link between stress and breast cancer. The most surprising positive study was the British one published by Chen [5] who reported an OR $=11,6$ for women subject to severe stress. Even if it is an accurately performed research, the study of Chen has long been debated, mostly because subsequent studies have not been able to reproduce its findings. The majority of positive articles relate an increase of around 2 times in the risk of breast cancer occurrence for women that experienced stressful life events. Controversially, there are several well conducted studies, such as Edwards's [37] or Michael's [64] that failed to show a relationship between stress and mammary carcinoma. These articles have drawn attention to the possibility of a complex psychosocial model, with a necessity to focus on biological and animal models.

\section{d. Moment of exposure / Time period investigated}

Taking into account the allostatic theory of McEwen [67] and the role of early stress as a risk factor of the allostatic load, as well as the doubling time of the tumor volume, which varies between 88 days and 2 years [68], for a psychological factor to be incriminated in oncogenesis, the stress must have acted a long time before diagnosis.

The dissonance between studies may be partially due to the time period taken into evaluation, a period that can be outside the relevant biological period. If we analyze the negative studies, we observe that 8 $[4,22,25,37,42,43,45,47]$ of them investigated periods of less than 5 years. Nevertheless, the longest prospective follow-up considered, belong also to negative studies $[57,62]$.

Another topic of discussion regards the impact of early stress. There are 4 studies $[31,32,38,56]$ that investigated and confirmed that stress in childhood and adolescence -coinciding with the moment of mammary development - have a negative influence on breast cancer development later in life.

\section{e. Interaction with other risk factors}

One of the biggest problems in determining the role of stress is the difficulty in isolating it as a solitary variable. Breast cancer presents a large number of demographic or physiological risk factors. All these factors have the potential to increase or decrease the psychological impact and vice versa. As an example $[28,42,43]$, stress has a more pronounced effect on young women, who tend to respond more severely to life events and who are also more prone to aggressive tumors. Social support is also implicated in stress management and therefore the lack of it can aggravate stress impact $[18,40,64]$. Smoking, alcohol consumption or obesity can also have a role in stress effect.

Essential risk factors as family history or other female physiological data are omitted in registry based studies. Such being the case, even if this type of studies have the highest degree of objectivity, their results must be regarded with suspicion. It is inaccurate to compare the death of a husband at a young age in a close family with a death at an old age, after a long period of disease or in a dysfunctional family.

\section{f. Individual susceptibility and personality}

Cancer is not a homogenous disease, as stressors are not generic and their effect is not identical. Individual susceptibility offers one of the explanations for the heterogeneous results in epidemiological studies. One's particular manner of responding to stress brings frequently into discussion the idea of a genetic predisposition of stress induced cancer.

Personality is one of the potential risk factors investigated due to its stability in time.

After accepting the role of a type A or B personality in different diseases, the notion of a type $\mathrm{C}$ personality has more frequently been discussed. It is characterized by the incapacity of an emotional expression of anger and by the tendency of supporting the needs of others and ignoring their own. Women are shy, calm, less curious [20,21], and usually suppress their anger [42]. Taking into consideration personality traits, the biopsy results have been correctly predicted in $75 \%$ of cases, and the discriminative analysis correctly identified $77 \%$ of women with cancer and $87 \%$ of women without cancer [50].

To summarize our research, the significantly large number of studies, as well as the impressive number of approximately 700,000 women analyzed, guarantees a comprehensive overview on the subject. Our results are consistent with those reported by other reviews and metaanalyses $[7,8]$.

\section{Study limitations}

Finally we acknowledge the shortcomings of our review. A single database was considered so there is the possibility of studies missed. We tried to exclude this error by also evaluating the list of references of the studies identified. There were two studies $[69,70]$ that were not accessible in full text, both of which dated from 1986 and were published in less known journals. Even if not analyzed, the abstracts state a positive involvement of psychosocial factors in breast cancer, which further confirms our results. Moreover, a statistical analysis by conducting a meta-analysis would have brought more objectivity, but would have implied the exclusion of many studies which did not calculate risk. We could even say a meta-analysis including all 52 studies is impossible to achieve, given the heterogeneity of evaluated stress and the various methods used.

\section{Clinical implications}

Clinical impact of stress in women is a matter of great interest. Stressful life events are difficult to predict or prepare for, but their possible role in breast cancer development can bring new insights in the prevention and treatment of this disease. Controlling stress factors using various self-learned techniques or using professional help to deal early with negative feelings, should definitely have 
a good effect on female health.

\section{Conclusions}

Stress is an imminent risk factor in our daily life and stressful events are real. A chronic exposure to stress has been linked to negative changes of body homeostasis. The role of stress in cancer has been extensively studied. Through this systematic review we focused on the epidemiological data regarding breast cancer. The qualitative analysis has shown a possible association between stressful events and breast cancer incidence. A final conclusion is difficult to be asserted because of the conflicting results. Elements of heterogeneity were discussed also. Possibly the role of experimental biology studies as a complementary method should be considered to measure the relationship between stressful life events and breast cancer development.

\section{References}

1. Ferlay J, Soerjomataram I, Ervik M, Dikshit R, Eser S, Mathers $\mathrm{C}$ et al. GLOBOCAN 2012 v 1.0, Cancer Incidence and Mortality Worldwide. 2013. Lyon, International Agency for Research on Cancer. IARC CancerBase No. 11.

2. Antonova L, Aronson K, Mueller CR. Stress and breast cancer: from epidemiology to molecular biology. Breast Cancer Res. 2011;13:208.

3. Snow HL. Cancer and the cancer process. J\&A. Churchill, London;1893, apud Bleiker EM, van der Ploeg HM. Psychosocial factors in the etiology of breast cancer: review of a popular link. Patient Educ Couns. 1999;37(3):201-214.

4. Roberts FD, Newcomb PA, Trentham-Dietz A, Storer BE. Selfreported stress and risk of breast cancer. Cancer. 1996;77:10891093.

5. Chen CC, David AS, Nunnerley H, Michell M, Dawson JL, Berry $\mathrm{H}$, et al. Adverse life events and breast cancer: case-control study. BMJ. 1995;311:1527-1530.

6. Petticrew M, Fraser JM, Regan MF. Adverse life-events and risk of breast cancer: a meta-analysis. Br J Health Psychol. 1999;4:1-17.

7. Duijts SF, Zeegers MP, Borne BV. The association between stressful life events and breast cancer risk: a meta-analysis. Int J Cancer. 2003;107(6):1023-1029.

8. Santos MC, Horta BL, Amaral JJ, Fernandes PF, Galvão CM, Fernandes AF. Association between stress and breast cancer in women: a meta-analysis. Cad Saude Publica. 2009;25 Suppl 3:S453-S463.

9. McKenna MC, Zevon MA, Corn B, Rounds J. Psychosocial factors and the development of breast cancer: a meta-analysis. Health Psychol. 1999;18:520-531.

10. Jensen AB. Psychosocial factors and breast cancer. A review. Ugeskr Laeger. 1992;154:3666-3670.

11. Butow PN, Hiller JE, Price MA, Thackway SV, Kricker A, Tennant CC. Epidemiological evidence for a relationship between life events, coping style, and personality factors in the development of breast cancer. J Psychosom Res. 2000;49:169-181.

12. Geyer S. The role of social and psychosocial factors in the development and course of cancer. Wien Klin Wochenschr. 2000;112:986-994.

13. Downs SH, Black N. The feasibility of creating a checklist for the assessment of the methodological quality both of randomised and non-randomised studies of health care interventions. J Epidemiol Community Health. 1998;52:377-384.

14. Oxford Centre for Evidence-based medicine Levels of Evidence (March 2009). Available from: http://www.cebm. net/oxford-centre-evidence-based-medicine-levels-evidencemarch-2009/

15. Hagnell O. The premorbid personality of persons who develop cancer în a total population investigated in 1947 and 1957. Ann N Y Acad Sci. 1966;125:846-855.

16. Wang L, Liao WC, Tsai CJ, Wang LR, Mao IF, Chen CC, et al The effects of perceived stress and life style leading to breast cancer. Women Health. 2013;53:20-40.

17. Toleutay U, Reznik V, Kalmatayeva Z, Smigelskas K. Risk factors of breast cancer in kyzylorda oblast of Kazakhstan: a casecontrol study. Asian Pac J Cancer Prev. 2013;14(10):5961-5964.

18. Price MA, Tennant CC, Butow PN, Smith RC, Kennedy SJ, Kossoff MB, et al. The role of psychosocial factors in the development of breast carcinoma: Part II. Life event stressors, social support, defense style, and emotional control and their interactions. Cancer. 2001;91:686-697.

19. Ginsberg A, Price S, Ingram D, Nottage E. Life events and the risk of breast cancer: a case-control study. Eur J Cancer. 1996;32A(12):2049-2052.

20. Jansen MA, Muenz LR. A retrospective study of personality variables associated with fibrocystic disease and breast cancer. $\mathrm{J}$ Psychosom Res. 1984;28(1):35-42.

21. Watson M, Pettingale KW, Greer S. Emotional control and autonomic arousal in breast cancer patients. J Psychosom Res. 1984;28(6):467-474.

22. Priestman TJ, Priestman SG, Bradshaw C. Stress and breast cancer. Br J Cancer. 1985;51:493-498.

23. Bremond A, Kune GA, Bahnson CB. Psychosomatic factors in breast cancer patients. Results of a case control study. J Psychosom Obstet Gyn. 1986;5:127-136.

24. Forsén A. Psychosocial stress as a risk for breast cancer. Psychother Psychosom. 1991;55(2-4):176-185.

25. Snell L, Graham S. Social trauma as related to cancer of the breast. Br J Cancer. 1971;25:721-734.

26. Ewertz M. Bereavement and breast cancer. Br J Cancer. 1986;53:701-703.

27. Kruk J, Aboul-Enein HY. Psychological stress and the risk of breast cancer: a case-control study. Cancer Detect Prev. 2004;28(6):399-408.

28. Peled R, Carmil D, Siboni-Samocha O, Shoham-Vardi I. Breast cancer, psychological distress and life events among young women. BMC Cancer. 2008 Aug 22;8:245. doi: 10.1186/14712407-8-245.

29. Tas F, Karalar U, Aliustaoglu M, Keskin S, Can G, Cinar FE. The major stressful life events and cancer: stress history and cancer. Med Oncol. 2012;29(2):1371-1377.

30. Kruk J. Self-reported psychological stress and the risk of breast cancer: a case-control study. Stress. 2012;15:162-171.

31. Scherg H, Blohmke M. Associations between selected life events and cancer. Behav Med. 1988 (Fall);14:119-124.

32. Keinan-Boker L, Vin-Raviv N, Liphshitz I, Linn S, Barchana M. Cancer incidence in Israeli Jewish survivors of World War II. J Natl Cancer Inst. 2009;101:1489-1500.

33. Anagnostopoulos F, Vaslamatzis G, Markidis M, Katsouyanni $\mathrm{K}$, Vassilaros S, Stefanis C. An investigation of hostile and alexithymic characteristics in breast cancer patients. Psychother Psychosom. 1993;59:179-189. 
34. Cheang A, Cooper CL. Psychosocial factors in breast cancer. Stress \& Health. 1985;1:61-66.

35. Cooper CL, Faragher EB. Psychosocial stress and breast cancer: the inter-relationship between stress events, coping strategies and personality. Psychol Med. 1993;23:653-662.

36. Cooper CL, Cooper R, Faragher EB. Incidence and perception of psychosocial stress: the relationship with breast cancer. Psychol Med. 1989;19:415-422.

37. Edwards JR, Cooper CL, Pearl SG, de Paredes ES, O'Leary T, Wilhelm MC. The relationship between psychosocial factors and breast cancer: some unexpected results. Behav Med. 1990;16:5-14. 38. Eskelinen M, Ollonen P. Life stress due to losses and deficit in childhood and adolescence as breast cancer risk factor: a prospective case-control study in Kuopio, Finland. Anticancer Res. 2010,30:4303-4308.

39. Fox CM, Harper AP, Hyner GC, Lyle RM. Loneliness, emotional repression, marital quality, and major life events in women who develop breast cancer. J Community Health. 1994; 19:467-482.

40. Geyer S. Life events prior to manifestation of breast cancer: a limited prospective study covering eight years before diagnosis. J Psychosom Res. 1991;35:355-363.

41. Grassi L, Cappellari L. State and trait psychological characteristics of breast cancer patients. New Trends Experim Clinical Psychol IV. 1988;22:99-109.

42. Greer S, Morris T. Psychological attributes of women who develop breast cancer: a controlled study. J Psychosom Res. 1975; 19:147-153.

43. Morris T, Greer S, Pettingale KW, Watson M. Patterns of expression of anger and their psychological correlates in women with breast cancer. J Psychosom Res. 1981;25:111-117.

44. Ollonen P, Lehtonen J, Eskelinen N. Stressful and adverse life experiences in patients with breast symptoms: a prospective casecontrol study in Kuopio, Finland. Anticancer Res. 2005;25:531536.

45. Protheroe D, Turvey K, Horgan K, Benson E, Bowers D, House A. Stressful life events and difficulties and onset of breast cancer: case-control study. BMJ. 1999;319:1027-1030.

46. Schonfield J. Psychological and life-experience differences between Israeli women with benign and cancerous breast lesions. J Psychosom Res. 1975;19:229-234.

47. Scherg H, Cramer I, Blohmke M. Psychosocial factors and breast cancer: a critical reevaluation of established hypotheses. Cancer Detect Prev. 1981;4:165-171.

48. Scherg H. Psychosocial factors and disease bias in breast cancer patients. Psychosom Med. 1987;49:302-312.

49. Todarello O, La Pesa MW, Zaka S, Martino V, Lattanzio E. Alexithymia and breast cancer. Survey of 200 women undergoing mammography. Psychother Psychosom. 1989;51:51-55.

50. Wirsching M, Hoffmann F, Stierlin H, Weber G, Wirsching B. Prebioptic psychological characteristics of breast cancer patients. Psychother Psychosom. 1985;43:69-76.

51. Lambe M, Cerrato R, Askling J, Hsieh CC. Maternal breast cancer risk after death of a child. Int J Cancer. 2004;110:763-766. 52. Kvikstad A, Vatten LJ, Tretli S, Kvinnsland S. Death of a husband or marital divorce related to risk of breast cancer în middleaged women. A nested case-control study among Norwegian women born 1935-1954. Eur J Cancer. 1994;30A(4):473-477.

53. Bleiker EM, van der Ploeg HM, Hendriks JH, Adèr HJ.

Personality factors and breast cancer development: a prospective longitudinal study. J Natl Cancer Inst. 1996;88:1478-1482.

54. Scherg H. Psychosocial factors in breast cancer and other cancers în retrospective and prospective view. In Muthny FA, Haag G, Eds, Onkologie im psychosoziale Kontext, Roland Ansager Verlag, Heidelberg, 1993, pp. 27-37.

55. Reynolds P, Kaplan GA. Social connections and risk for cancer: prospective evidence from the Alameda County Study. Behav Med. 1990;16:101-110.

56. Jacobs JR, Bovasso GB. Early and chronic stress and their relation to breast cancer. Psychol Med. 2000;30(3):669-678.

57. Johansen C, Olsen JH. Psychological stress, cancer incidence and mortality from non-malignant diseases. $\mathrm{Br} \mathrm{J}$ Cancer. 1997; 75:144-148.

58. Lillberg K, Verkasalo PK, Kaprio J, Teppo L, Helenius H, Koskenvuo M. Stress of daily activities and risk of breast cancer: a prospective cohort study în Finland. Int J Cancer. 2001;91:888-893. 59. Helgesson O, Cabrera C, Lapidus L, Bengtsson C, Lissner L. Self-reported stress levels predict subsequent breast cancer in a cohort of Swedish women. Eur J Cancer Prev. 2003;12:377-381. 60. Metcalfe C, Davey Smith G, Macleod J, Hart C. The role of self-reported stress in the development of breast cancer and prostate cancer: a prospective cohort study of employed males and females with 30 years of follow-up. Eur J Cancer. 2007;43:10601065.

61. Kroenke $\mathrm{CH}$, Hankinson SE, Schernhammer ES, Colditz GA, Kawachi I, Holmes MD. Caregiving stress, endogenous sex steroid hormone levels, and breast cancer incidence. Am J Epidemiol. 2004;159:1019-1027.

62. Nielsen NR, Zhang ZF, Kristensen TS, Netterstrøm B, Schnohr P, Grønbaek M. Self reported stress and risk of breast cancer: prospective cohort study. BMJ. 2005 Sept 10;331(7516):548.

63. Surtees PG, Wainwright NW, Luben RN, Khaw KT, Bingham SA. No evidence that social stress is associated with breast cancer incidence. Breast Cancer Res Treat. 2010;120:169-174.

64. Michael YL, Carlson NE, Chlebowski RT, Aickin M, Weihs $\mathrm{KL}$, Ockene JK, et al. Influence of stressors on breast cancer incidence in the Women's Health Initiative. Health Psychol. 2009;28:137-146.

65. MacLehose RR, Reeves BC, Harvey IM, Sheldon TA, Russell IT, Black AM. A systematic review of comparisons of effect sizes derived from randomised and non-randomised studies. Health Technol Assess. 2000;4(34):1-154.

66. Brugha TS, Cragg D. The list of threatening experiences: the reliability and validity of a brief life events questionnaire. Acta Psychiatr Scand. 1990;82(1):77-81.

67. McEwen BS. The neurobiology of stress: from serendipity to clinical relevance. Brain Res. 2000;886:172-189.

68. Friberg S, Mattson S. On the growth rates of human malignant tumors: implications for medical decision making. J Surg Oncol. 1997;65:284-297.

69. Ioannidou-Mouzaka L, Mantonakis J, Toufexi H, Tsiliakos $\mathrm{S}$, Agnantis NJ. Is prolonged psychological stress an etiological factor in breast cancer?. J Gynecol Obstet Biol Reprod (Paris). 1986;15:1049-1053.

70. Terra JL, Amiel-Lebigre F, Boujema F, Guyotat J, GuillaudBataille JM, Jurus M, et al. Evènements de la vie et cancer du sein: premiers resultants d'une etude comparative portent sur 100 cas et leurs témoins [Life events and breast cancer: first results of a comparative study on 100 case controlled cases]. Acta Psychiatr Belg. 1986;86:496-501. 